\title{
Stroke in cancer patients: a risk factor analysis
}

\author{
Stefan Oberndorfer - Vera Nussgruber · \\ Otto Berger · Heinz Lahrmann · Wolfgang Grisold
}

Published online: 28 April 2009

(C) Springer Science+Business Media, LLC. 2009

\section{Erratum to: J Neurooncol}

\section{DOI 10.1007/s11060-009-9818-3}

The author given names were shown as family names and vice versa in the original publication.

The online version of the original article can be found under doi:10.1007/s11060-009-9818-3.

S. Oberndorfer $(\bowtie) \cdot$ V. Nussgruber $\cdot$ O. Berger .

H. Lahrmann - W. Grisold

Department Neurology and LBI-Neurooncology, KFJ-Hospital,

Kundratstrasse 3, 1100 Vienna, Austria

e-mail: stefan.oberndorfer@wienkav.at 